\title{
Cassava interspecific hybrids with increased protein content and improved amino acid profiles
}

\author{
P.T.C. Gomes and N.M.A. Nassar \\ Universidade de Brasília, Brasília, DF, Brasil \\ Corresponding author: N.M.A. Nassar \\ E-mail: nagnassa@rudah.com.br \\ Genet. Mol. Res. 12 (2): 1214-1222 (2013) \\ Received February 27, 2013 \\ Accepted March 26, 2013 \\ Published April 12, 2013 \\ DOI http://dx.doi.org/10.4238/2013.April.12.8
}

\begin{abstract}
Cassava (Manihot esculenta) is a principal food for large populations of poor people in the tropics and subtropics. Its edible roots are poor in protein and lack several essential amino acids. Interspecific hybrids may acquire high protein characteristics from wild species. We analyzed 19 hybrids of $M$. esculenta with its wild relative, $M$. oligantha, for crude protein, amino acid profile, and total cyanide. Some hybrids produced roots with high protein content of up to $5.7 \%$, while the common cultivar that we examined had just $2.3 \%$ crude protein. The essential amino acids alanine, phenylalanine, and valine were detected in the hybrids. The sulfur-containing amino acids cysteine and methionine were found at relatively high concentrations in the roots of 4 hybrids. The proportion of lysine in one hybrid was 20 times higher than in the common cultivar. The levels of total cyanide ranged from 19.73 to $172.56 \mathrm{mg} / \mathrm{kg}$ and most of the roots analyzed were classified as "non-toxic" and "low toxic". Furthermore, 2 progenies showed reasonable levels of cyanide, but higher protein content and amino acid profile more advantageous than the common cassava.
\end{abstract}

Key words: Cassava; Interspecific hybrids; Protein; Essential amino acids 


\section{INTRODUCTION}

Cassava, Manihot esculenta Crantz, is the main food for more than 800 million poor people in the tropics and subtropics (FAO, 2007). Its edible roots are consumed in many different ways; however, they are poor in protein content, which is no more than $2 \%$ in common cultivars.

Wild relatives of cassava are found to contain higher amounts of protein, and hybrids were produced by Nassar for this reason (Nassar, 1978; Nassar and Dorea, 1982). Nassar and colleagues have continued to produce hybrids over the last 30 years. These hybrids are propagated and maintained in the living collection at Universidade de Brasília.

In this study, we determined crude protein contents, amino acid profiles and cyanide levels of the interspecific hybrids and of the common cassava.

\section{MATERIAL AND METHODS}

Three distinct groups were used: the common cassava, diploid hybrids, and tetraploid hybrids. The common cassava cultivar, called "530 cultivar", is a common and popular cassava cultivar in Brasília, DF, Brazil, selected for table consumption from indigenous cassava.

The hybrid ICB 300 was produced by crossing cassava with the wild species M. oligantha (Nassar and Dorea, 1982). The diploid interspecific hybrids are the progenies of ICB 300 , which were allowed to cross by open pollination. They are designated progenies of ICB 300 (Table 1). All of them are diploid $(2 \mathrm{n}=36)$.

\begin{tabular}{ll}
\multicolumn{1}{c}{ Table 1. Plants of the 3 different groups studied. } \\
\hline Group & Plant \\
\hline Common cassava & 530 cultivar \\
Diploid hybrids & ICB 300 \\
& ICB 300-3 \\
& ICB 300-5 \\
& ICB 300-7 \\
& ICB 300-10 \\
& ICB 300-12 \\
& ICB 300-17 \\
& ICB 300-18 \\
ICB 300-25 \\
ICB 300-34 \\
ICB 300-37 \\
ICB 300-38 \\
ICB 300 TE \\
ICB 300 TE-2 \\
ICB 300 TE-8 \\
ICB 300 TE-10 \\
ICB 300 TE-12 \\
ICB 300 TE-15 \\
ICB 300 TE-16
\end{tabular}

A tetraploid type called ICB 300 TE was analyzed. It originated from polyploidyzation of ICB 300 using colchicine followed by vegetative propagation. Progenies from open pollination, which were found to be tetraploid, were also analyzed.

All the interspecific hybrids and the common cassava cultivar analyzed in this study are part of the living Collection of Cassava, established at the Biological Experimental Station of Universidade the Brasília. 


\section{Amino acid profile analysis}

Cassava roots were washed, peeled, and sliced into thin sections. The sections were macerated under liquid nitrogen, and the mass obtained was lyophilized.

The amino acid profile was determined by high-performance liquid chromatography as described by Nassar and Sousa (2007). The samples of cassava root powder were submitted to acid extraction followed by alkaline extraction. The extracts were then mixed, and the total extract was submitted to acid hydrolysis for $24 \mathrm{~h}$ under vacuum. The hydrolyzed samples were then diluted in $100 \mathrm{mM} \mathrm{HCl}$ and injected into an amino acid analyzer (Hitachi L8500). Determination of amino acid composition was performed in triplicate for each plant.

\section{Analysis of protein content}

The roots were washed, peeled, and dried in an air oven at $37^{\circ} \mathrm{C}$ for $72 \mathrm{~h}$. The dried rhizome was grounded using a Wiley laboratory mill.

The crude protein content was assessed by determination of total nitrogen by converting organic nitrogen into ammonium ion, as described by the Kjeldahl method (Official Methods of Analysis, 2000). This step was followed by the determination of ammonium ion by photocolorimetry, according to the method proposed by Baethgen and Alley (1989). Protein level was estimated by multiplying the nitrogen percentage by 3.24 as proposed by Hock-Hin and Van-Den (1996).

\section{Cyanide evaluation}

The technique proposed by Brito et al. (2009) was used to measure cyanide. The method involves the hydrolysis of linamarin by endogenous linamarase in the assay sample. The released cyanide reacts with a picrate solution, and absorbance is then read in a spectrophotometer.

\section{RESULTS AND DISCUSSION}

\section{Crude protein}

There was great variation in crude protein levels between the 20 plants evaluated, ranging from 1.80 to $5.78 \%$ (Table 2). The hybrids ICB 300-34, ICB 300-18, and ICB 300-38 showed the highest protein content, with 5.78, 5.71, and 5.64\%, respectively. These values were higher than that observed in their progenitor, ICB-300, with $3.50 \%$ protein. Other progenies of ICB-300 (ICB 300-12 and ICB 300-17) also had higher protein levels than the progenitor.

This finding can be explained by "positive segregation" (Allard, 1960), that is a case of quantitative inheritance, controlled by more than 1 allele pair where the progenitor is heterozygous for these alleles. An opposite phenomenon, "negative segregation", was seen in the progenies ICB 300-10 (2.50\%) and ICB 300-25 (2.16\%), which showed lower percentages of crude protein compared to ICB 300 (Table 2).

The protein level of $2.30 \%$ found for the common cultivar, plant 530, agrees with literature reports indicating 1 to $3 \%$ crude protein in cassava roots (Buitrago, 1990; Balagopalan et al., 1992; Babu and Chatterjee, 1999). 


\begin{tabular}{ll} 
Table 2. Crude protein contents of the roots studied. \\
\hline Plant & Protein (\%) \\
\hline ICB 300-34 & $5.78 \pm 0.20^{\mathrm{a}}$ \\
ICB 300-18 & $5.71 \pm 0.37^{\mathrm{a}}$ \\
ICB 300-38 & $5.64 \pm 0.01^{\mathrm{a}}$ \\
ICB 300-12 & $5.33 \pm 0.37^{\mathrm{ab}}$ \\
ICB 300 TE & $5.09 \pm 0.05^{\mathrm{b}}$ \\
ICB 300-7 & $4.35 \pm 0.10^{\mathrm{c}}$ \\
ICB 300-17 & $3.88 \pm 0.15^{\mathrm{cd}}$ \\
ICB 300 & $3.50 \pm 0.01^{\mathrm{de}}$ \\
ICB 300-3 & $3.44 \pm 0.02^{\mathrm{de}}$ \\
ICB 300-37 & $3.42 \pm 0.07^{\mathrm{de}}$ \\
ICB 300-5 & $3.06 \pm 0.08^{\mathrm{ef}}$ \\
ICB 300 TE-2 & $2.56 \pm 0.01^{\mathrm{gg}}$ \\
ICB 300 TE-12 & $2.51 \pm 0.06^{\mathrm{gh}}$ \\
ICB 300-10 & $2.50 \pm 0.35^{\mathrm{gh}}$ \\
ICB 300 TE-15 & $2.36 \pm 0.15^{\mathrm{gh}}$ \\
530 cultivar & $2.30 \pm 0.06^{\mathrm{ghi}}$ \\
ICB 300 TE-10 & $2.29 \pm 0.04^{\mathrm{ghi}}$ \\
ICB 300-25 300 TE-16 & $2.16 \pm 0.06^{\mathrm{ghi}}$ \\
ICB 300 TE-8 & $1.97 \pm 0.12^{\mathrm{hi}}$ \\
\hline D. & $1.80 \pm 0.09^{\mathrm{i}}$ \\
\hline
\end{tabular}

Data are reported as means \pm standard deviation. Crude protein content is related to dry matter. Values followed by the same superscript letters are not significantly different for $\mathrm{P}<0.05$.

The low levels of crude protein observed for tetraploid progeny in comparison with the tetraploid progenitor (ICB 300 TE) (Table 2) were due to genetic segregation. In tetraploids, it includes 4 alleles compared to 2 alleles in diploids, resulting in such combinations and permutations.

We used the factor 3.24 for converting Kjeldahl nitrogen to protein percentage in place of 6.25. Using the latter would result in higher percentages of protein. The factor chosen, however, appears to be more reliable, since cassava is considered to have high amounts of non-protein nitrogen (Simmons et al., 2008; Gomes and Nassar, 2008).

Comparing the coefficient of variation of the 3 cassava groups (Table 3), it is noted that tetraploid cassava roots showed the highest coefficient of variation $(41.78 \%)$, while it was only $2.60 \%$ for the common cassava. The total population also demonstrated a high coefficient of variation (39.35\%), which may indicate a greater possibility of improving this trait.

Table 3. Comparison between crude protein content of the groups studied.

\begin{tabular}{lccr}
\hline Group & & Crude protein in dry weight basis \\
\cline { 2 - 4 } & Mean (\%) & SD & CV (\%) \\
\hline Diploid & 4.06 & 1.28 & 31.52 \\
Tetraploid & 2.65 & 1.10 & 41.78 \\
Common cassava & 2.30 & 0.06 & 2.60 \\
Total population & 3.48 & 1.37 & 39.35 \\
\hline
\end{tabular}

Data are reported as means, standard deviation, and coefficient of variation. Crude protein content is related to dry matter.

Moreover, the levels of crude protein shown by ICB 300-34, ICB 300-18, ICB 30038, ICB 300-12, ICB 300 TE, ICB 300-7, ICB 300-17, ICB 300, ICB 300-3, ICB 300-37, and ICB 300-5 were higher than that of the common cassava. Thus, these plants demonstrated a substantial potential to be developed into cultivars with higher protein content. 


\section{Amino acid profile}

The total amino acid compositions of the cassava roots are given in Tables 4, 5 and 6. The values corresponded to grams of amino acid per $100 \mathrm{~g}$ amino acid extract. The amino acid extract consisted of free- and protein-derived amino acids in the root samples. It was not possible to determine the amount of tryptophan, which is degraded during acid hydrolysis (Nassar and Sousa, 2007).

Table 4. Amino acid profile of roots of the 530 cultivar, the interspecific hybrid ICB 300, and its 4 progenies.

\begin{tabular}{|c|c|c|c|c|c|c|}
\hline \multirow[t]{2}{*}{ Amino acid } & 530 cultivar & ICB 300 & ICB 300-3 & ICB $300-5$ & ICB $300-7$ & ICB $300-10$ \\
\hline & \multicolumn{6}{|c|}{ Composition of amino acids $(\mathrm{g} / 100 \mathrm{~g})$} \\
\hline Asparagine & 4.06 & 3.21 & 3.74 & 3.68 & 5.17 & 5.49 \\
\hline Threonine & 1.59 & 1.52 & 2.66 & 2.16 & 2.17 & 3.41 \\
\hline Serine & 2.64 & 2.53 & 4.79 & 3.18 & 3.39 & 2.70 \\
\hline Glutamine & 51.95 & 34.00 & 45.88 & 28.41 & 22.18 & 33.33 \\
\hline Glycine & 2.33 & 1.61 & 1.95 & 2.08 & 2.98 & 3.07 \\
\hline Alanine & 8.53 & 7.82 & 6.91 & 6.79 & 14.11 & 14.98 \\
\hline Cysteine & 1.12 & 3.46 & 0.60 & 5.04 & 0.85 & 0.82 \\
\hline Valine & 2.37 & 3.11 & 2.58 & 4.69 & 2.40 & 2.51 \\
\hline Methionine & 1.45 & 3.32 & 0.88 & 4.74 & 1.13 & 1.58 \\
\hline Isoleucine & 0.93 & 1.88 & 1.31 & 2.37 & 1.17 & 1.56 \\
\hline Leucine & 1.28 & 2.45 & 1.27 & 3.19 & 1.79 & 1.93 \\
\hline Tyrosine & 0.00 & 0.00 & 0.00 & 0.94 & 0.00 & 0.04 \\
\hline Phenylalanine & 1.96 & 2.98 & 1.89 & 3.33 & 2.90 & 3.10 \\
\hline Lysine & 1.76 & 1.61 & 1.72 & 1.89 & 2.23 & 1.98 \\
\hline Histidine & 3.85 & 5.70 & 2.81 & 3.77 & 4.52 & 3.24 \\
\hline Arginine & 12.18 & 23.78 & 17.74 & 23.13 & 28.52 & 15.16 \\
\hline Proline & 2.01 & 1.02 & 3.27 & 0.62 & 4.48 & 5.10 \\
\hline Total & 100.00 & 100.00 & 100.00 & 100.00 & 100.00 & 100.00 \\
\hline
\end{tabular}

Table 5. Amino acid profile of roots of the 7 progenies of ICB 300.

\begin{tabular}{|c|c|c|c|c|c|c|c|}
\hline \multirow[t]{2}{*}{ Amino acid } & ICB $300-12$ & ICB $300-17$ & ICB 300-18 & ICB $300-25$ & ICB 300-34 & ICB 300-37 & ICB $300-38$ \\
\hline & \multicolumn{7}{|c|}{ Composition of amino acids $(\mathrm{g} / 100 \mathrm{~g})$} \\
\hline Asparagine & 7.46 & 2.80 & 4.92 & 3.87 & 5.24 & 10.60 & 3.50 \\
\hline Threonine & 3.95 & 1.99 & 2.35 & 2.20 & 0.83 & 1.09 & 2.15 \\
\hline Serine & 4.52 & 2.55 & 2.69 & 3.61 & 0.73 & 2.24 & 2.91 \\
\hline Glutamine & 21.61 & 23.33 & 43.65 & 42.73 & 58.51 & 26.50 & 30.32 \\
\hline Glycine & 0.00 & 2.68 & 2.63 & 2.66 & 0.00 & 2.69 & 2.77 \\
\hline Alanine & 8.24 & 10.97 & 14.23 & 7.49 & 0.00 & 1.70 & 9.80 \\
\hline Cysteine & 20.23 & 2.07 & 0.86 & 0.47 & 21.13 & 8.67 & 3.26 \\
\hline Valine & 3.42 & 0.28 & 2.53 & 2.11 & 2.38 & 2.42 & 0.01 \\
\hline Methionine & 0.42 & 0.68 & 1.36 & 1.16 & 0.00 & 4.48 & 0.86 \\
\hline Isoleucine & 1.76 & 1.08 & 1.34 & 1.20 & 0.27 & 0.61 & 1.02 \\
\hline Leucine & 4.51 & 1.56 & 1.89 & 1.59 & 0.27 & 0.68 & 1.49 \\
\hline Tyrosine & 0.00 & 0.00 & 0.00 & 0.01 & 0.00 & 0.00 & 0.00 \\
\hline Phenylalanine & 3.74 & 1.45 & 3.14 & 2.34 & 0.00 & 2.35 & 1.44 \\
\hline Lysine & 0.92 & 7.99 & 1.69 & 2.21 & 0.00 & 1.57 & 10.16 \\
\hline Histidine & 0.00 & 4.64 & 3.21 & 3.73 & 0.00 & 0.00 & 5.27 \\
\hline Arginine & 19.20 & 33.28 & 10.54 & 18.59 & 10.65 & 34.37 & 21.12 \\
\hline Proline & 0.00 & 2.64 & 2.98 & 4.04 & 0.00 & 0.00 & 3.90 \\
\hline Total & 100.00 & 100.00 & 100.00 & 100.00 & 100.00 & 100.00 & 100.00 \\
\hline
\end{tabular}

There are reports in the literature that the common cassava has low levels of cysteine, isoleucine, and methionine (Hock-Hin and Van-Den, 1996; Gil and Buitrago, 2002). The results 
of this study differed since we found $1.28 \mathrm{~g} / 100 \mathrm{~g}$ cysteine, $0.93 \mathrm{~g} / 100 \mathrm{~g}$ alanine, and $1.59 \mathrm{~g} / 100 \mathrm{~g}$ methionine for the cultivar UnB 530, which represents the common cassava (Table 4). There were high levels of glutamine, alanine, and asparagine, as previously reported by the above cited authors.

\begin{tabular}{|c|c|c|c|c|c|c|c|}
\hline \multirow[t]{2}{*}{ Amino acid } & ICB $300 \mathrm{TE}$ & ICB 300 TE-2 & ICB 300 TE-8 & ICB 300 TE-10 & ICB 300 TE-12 & ICB 300 TE-15 & ICB 300 TE-16 \\
\hline & \multicolumn{7}{|c|}{ Composition of amino acids (g/100 g) } \\
\hline Asparagine & 7.82 & 3.98 & 4.53 & 5.05 & 7.29 & 6.75 & 6.93 \\
\hline Threonine & 2.44 & 2.33 & 2.32 & 2.95 & 2.09 & 2.29 & 3.17 \\
\hline Serine & 4.49 & 3.19 & 2.96 & 4.56 & 2.58 & 3.74 & 3.90 \\
\hline Glutamine & 3.14 & 2.49 & 1.82 & 5.25 & 2.50 & 2.98 & 4.03 \\
\hline Glycine & 15.22 & 11.98 & 8.64 & 16.70 & 10.42 & 10.82 & 16.84 \\
\hline Alanine & 1.13 & 1.01 & 1.58 & 1.78 & 0.00 & 1.22 & 1.47 \\
\hline Cysteine & 2.93 & 2.81 & 2.47 & 4.18 & 2.65 & 2.71 & 4.16 \\
\hline Valine & 1.63 & 1.59 & 0.66 & 2.12 & 0.61 & 1.69 & 1.62 \\
\hline Methionine & 1.28 & 1.33 & 1.12 & 1.87 & 1.23 & 1.37 & 1.63 \\
\hline Isoleucine & 2.12 & 1.96 & 1.59 & 3.01 & 1.90 & 2.08 & 2.82 \\
\hline Leucine & 0.00 & 0.00 & 0.00 & 0.00 & 0.00 & 0.00 & 0.00 \\
\hline Tyrosine & 4.40 & 3.24 & 2.46 & 3.85 & 2.47 & 2.10 & 4.11 \\
\hline Phenylalanine & 1.93 & 2.04 & 1.68 & 3.42 & 1.30 & 1.55 & 1.94 \\
\hline Lysine & 4.98 & 2.65 & 3.96 & 5.34 & 4.08 & 2.55 & 3.03 \\
\hline Histidine & 19.38 & 20.19 & 26.62 & 15.82 & 6.86 & 4.53 & 9.43 \\
\hline Arginine & 7.52 & 3.76 & 1.68 & 3.04 & 4.36 & 7.60 & 4.47 \\
\hline Total & 100.00 & 100.00 & 100.00 & 100.00 & 100.00 & 100.00 & 100.00 \\
\hline
\end{tabular}

The amino acid composition of the diploid interspecific hybrid ICB 300 was similar to that found by Nassar and Sousa (2007). We found a high proportion of the essential amino acids glutamine and arginine. Its content of arginine and other essential amino acids, namely methionine, cysteine, and histidine, was about 2-fold higher than that determined for the common cassava (Table 4). The progenies ICB 300-5 (Table 4) and ICB 300-37 (Table 5) showed high proportions of methionine. ICB 300-5 had a high content of valine, another essential amino acid that was found in higher amounts than in the common cassava.

The sulfur-containing amino acid cysteine was found to be 20 times higher in the progenies ICB 300-12 and ICB 300-34 (Table 5) than in the common cassava (Table 4). The presence of higher amounts of cysteine in cassava roots is important, because this amino acid is involved in the detoxification of cyanide released by cassava and its derivative products (Osuntokun et al., 1968).

The progenies ICB 300-38 and ICB 300-17 exhibited high amounts of lysine (Table 6), when compared with those of the common cassava (Table 4). Lysine is one of the limiting amino acids in the cassava root protein (Young and Pellet, 1994; Millward, 1999). The high content of lysine in ICB 300-38 and ICB-17 indicates the biological value of the protein in the roots of these hybrids, because of the better balance between essential and non-essential amino acids.

Together with the study of Nassar and Sousa (2007), this is the first report of interspecific hybrids of cassava with such favorable amino acid profile, which supports the notion that certain wild species of cassava may contribute to high protein content and good-quality amino acids for the common cassava.

\section{Total cyanide}

Levels of total cyanide ranged from 19.73 to $172.56 \mathrm{mg} / \mathrm{kg}$, as indicated in Table 7 . The hybrids ICB 300 TE-10, ICB 300 TE-8, and ICB 300 TE-16 exhibited the lowest cyanide 
levels. On the other hand, ICB 300-37, ICB 300-18, and ICB 300 TE showed the highest cyanide content (Table 7).

\begin{tabular}{lc} 
Table 7. Total cyanide of the roots of cassava analysed. \\
\hline Plant & HCN $(\mathrm{mg} / \mathrm{kg})$ \\
\hline ICB 300 TE-10 & $19.73 \pm 0.00^{\mathrm{a}}$ \\
ICB 300 TE-8 & $31.50 \pm 0.19^{\mathrm{b}}$ \\
ICB 300 TE-16 & $33.39 \pm 2.52^{\mathrm{b}}$ \\
ICB 300 TE-2 & $36.39 \pm 0.33^{\mathrm{bc}}$ \\
ICB 300-25 & $41.61 \pm 1.02^{\mathrm{c}}$ \\
530 cultivar & $50.61 \pm 0.96^{\mathrm{d}}$ \\
ICB 300-7 & $54.94 \pm 0.77^{\mathrm{de}}$ \\
ICB 300-12 & $56.27 \pm 2.79^{\mathrm{e}}$ \\
ICB 300 TE-15 $300-10$ & $66.60 \pm 1.64^{\mathrm{f}}$ \\
ICB 300-5 & $73.04 \pm 0.67^{\mathrm{g}}$ \\
ICB 300 TE-12 & $78.15 \pm 1.54^{\mathrm{gh}}$ \\
ICB 300 & $80.71 \pm 0.33^{\mathrm{h}}$ \\
ICB 300-17 & $83.15 \pm 0.69^{\mathrm{h}}$ \\
ICB 300-34 $300-38$ & $93.26 \pm 1.35^{\mathrm{i}}$ \\
ICB 300-3 & $98.48 \pm 0.51^{1 \mathrm{j}}$ \\
ICB 300 TE & $99.92 \pm 0.19^{\mathrm{j}}$ \\
ICB 300-18 & $110.25 \pm 2.04^{\mathrm{k}}$ \\
ICB 300-37 & $130.58 \pm 1.95^{1^{\mathrm{j}}}$ \\
\hline
\end{tabular}

Data are reported as means \pm standard deviation. Total cyanide refers to fresh pulp of the roots. Values followed by same superscript letters are not significantly different for $\mathrm{P}<0.05$.

According to classification suggested by Coursey (1973), the hybrids ICB 300 TE-10, ICB 300 TE-8, ICB 300 TE-16, ICB 300 TE-2, ICB 300-25, and 530 cultivar can be classified as "non-toxic". The plants ICB 300-7, ICB 300-12, ICB 300 TE-15, ICB 300-10, and ICB 300-5 are "low toxic", while ICB 300 TE-12, ICB 300, ICB 300-17, ICB 300-34, and ICB 300-38 are classified as "toxic". Four of the plants studied can be placed in the category "highly toxic": ICB 300-3, ICB 300 TE, ICB 300-18, and ICB 300-37 (Table 8).

Table 8. Categorization of the plants studied according to Coursey, 1973.

\begin{tabular}{ll}
\hline Classification & Plants \\
\hline Non-toxic $(<50 \mathrm{mg} / \mathrm{kg}$ cyanide $)$ & 530 cultivar \\
& ICB 300-25 \\
& ICB 300 TE-2 \\
& ICB 300 TE- 8 \\
Low toxic $(50$ to $80 \mathrm{mg} / \mathrm{kg}$ cyanide $)$ & ICB 300 TE- 10 \\
& ICB 300 TE-16 \\
& ICB 300-5 \\
Toxic $(80$ to $100 \mathrm{mg} / \mathrm{kg}$ cyanide $)$ & ICB 300-7 \\
& ICB 300-10 \\
Highly toxic $(>100 \mathrm{mg} / \mathrm{kg}$ cyanide $)$ & ICB 300-12 \\
& ICB 300 TE-15 \\
& ICB 300 \\
& ICB 300-17 \\
& ICB 300-34 \\
& ICB 300-38 \\
& ICB 300 TE- 12 \\
& ICB 300-3 \\
& ICB 300-18 \\
& ICB 300-37 \\
& ICB 300 TE
\end{tabular}




\section{CONCLUSIONS}

In this study, we identified cassava hybrids with high protein content combined with advantageous amino acid profile and moderate cyanide levels, particularly the hybrids ICB 300-7 and ICB 300-12.

The hybrids ICB 300-7 and ICB 300-12 showed low cyanide levels, similar to those of the common cassava (UnB 530 cultivar). They showed very high protein contents of 4.35 and $5.33 \%$, respectively. Besides, ICB 300-7 had a different amino acid profile, with higher amounts of alanine, arginine, and proline compared to the common cassava. In turn, ICB 300-12 demonstrated a valuable amino acid profile, with high levels of threonine, cysteine, leucine, phenylalanine, and arginine. These 2 hybrids have a potential to become cassava cultivars with superior nutritional quality compared to the common cultivars. The consumption of the roots of these hybrids could offer higher quantities of nutrients than those available in the common cassava.

Our findings confirm that wild species of cassava and its hybrids are invaluable sources of protein, amino acids, and other nutrients. This source still needs to be explored by breeders.

\section{ACKNOWLEDGMENTS}

Thanks are due to the National Council for Scientific Development (CNPq), Brasília, DF, and Coordination for Qualifying Graduates (CAPES). The living collection of wild cassava was established at Universidade de Brasília in 1980 with the help of the Canadian International Center for Research Development (IDRC). We are thankful to Professors M.V. de Sousa, Universidade de Brasília, M.P. Cereda, Universidade Católica Dom Bosco, and I.M. Vasconcelos, Universidade Federal do Ceará, for laboratory assistance.

\section{REFERENCES}

Allard RW (1960). Principles of Plant Breeding. John Willey \& Sons, Inc., New York.

Babu L and Chatterjee SR (1999). Protein content and amino acid composition of cassava tubers and leaves. J. Root Crops 25: $163-168$.

Baethgen WE and Alley MM (1989). A manual colorimetric procedure for measuring ammonium nitrogen in soil and plant Kjeldahl digest. Commun. Soil Sci. Plan. 20: 961-969.

Brito VHS, Ramalho RT, Rabacow APM, Moreno SE, et al. (2009). Colorimetric method for free and potential cyanide analysis of cassava tissue. Gene Conserve 8: 841-852.

Buitrago AJA (1990). La Yuca en la Alimentación Animal. Centro Internacional de Agricultura Tropical, Cali.

Coursey DG (1973). Cassava as Food: Toxicity and Technology. In: Chronic Cassava Toxicity (Nestel BL and MacIntyre R, eds.). IDRC, Ottawa, 27-36.

FAO (2007). Production Yearbook. Rome.

Gil JL and Buitrago AJA (2002). La Yuca en la Alimentacion Animal. In: La Yuca en el Tercer Milenio: Sistemas Modernos de Producción, Procesamiento, Utilización y Comercialización. CIAT, Clayuca, Ministerio de Agricutura y Desarrollo Rural y Fenavi. Centro Internacional de Agricultura Tropical, Cali, 527-568.

Gomes PTC and Nassar NM (2008). Comment on Article: Variation in crude protein content in cassava (Manihot esculenta Crantz) roots. Gene Conserve 7: 606-607.

Hock-Hin Y and Van-Den T (1996). Protein contents, amino acid compositions and nitrogen-to-protein conversion factors for cassava roots. J. Sci. Food Agr. 70: 51-54.

Millward DJ (1999). The nutritional value of plant-based diets in relation to human amino acid and protein requirements. Proc. Nutr. Soc. 58: 249-260.

Nassar NM (1978). Conservation of the genetic resources of cassava (Manihot esculenta); determination of wild species localities with emphasis on probable origin. Econ. Bot. 32: 311-320. 
Nassar NM and Dorea JG (1982). Protein contents of cassava cultivars and its hybrid with Manihot species. Turrialba 32: 429-432.

Nassar NM and Sousa MV (2007). Amino acid profile in cassava and its interspecific hybrid. Genet. Mol. Res. 6: 292-297. Official Methods of Analysis (2000). 17th edn. AOAC International, Washington.

Osuntokun BO, Durowoju JE, McFarlane H and Wilson J (1968). Plasma amino-acids in the Nigerian nutritional ataxic neuropathy. Br. Med. J. 3: 647-649.

Simmons A, Abhary M and Fauquet C (2008). “Total Protein” Content Versus True Protein in Cassava Roots. Proceedings of the First Scientific Meeting of the Global Cassava Partnership (GCP-10). Ghent University, Ghent.

Young VR and Pellett PL (1994). Plant proteins in relation to human protein and amino acid nutrition. Am. J. Clin. Nutr. 59: 1203S-1212S. 